DOI https://doi.org/10.36059/978-966-397-216-9/5-23

\title{
THE ROLE OF C. CZERNY IN F. LISZT'S MUSICAL FATE
}

\section{Genkin A. A.}

\section{INTRODUCTION}

The theme of C. Czerny and F. Liszt is immense in its content and ways of study. The issues involved are extremely broad, and the main one is what a great Hungarian inherits from his venerable teacher: pedagogical principles or specific recommendations of a technical plan; a taste for mentoring or advice on improvisation, repertoire, his "address", or is it a spiritual and aesthetic influence? These and a number of other issues that arise involuntarily when confronted with such complex, subtle, and delicate matter, which emerges from the communication of two remarkable celebrities, deserve their special study. They are partially covered in an extended article by R. Mueller / Rena Charnin Mueller under the moving title "Acknowledgment of Liszt to Czerny" [12] ${ }^{1}$. As the author proceeds from the information contained in the works and memoirs of K. Czerny, his correspondence with F. Liszt made by him on this basis of observation is expedient to be stated in this section of our theses, preceding the analytical excursion to the origins of F. Liszt's pianism when he created the first series of sketches. At the same time, their information and conclusions provided in the article, as well as the special attention to refraction of pedagogical ideas of C. Czerny in these sketches, etc., sheds light on the creative problems, the solution of which served as a starting mechanism for the thorny path of F. Liszt in music art. Perhaps equally important is the spiritual and aesthetic "nourishment" of F. Liszt to the musical ideas and visions of C. Czerny, which had been practiced for many years. In communication with the mentor, the mature master specified his own positions in the art, including in composition. For this reason, not only because of the short duration of direct discipleship, F. Liszt considered C. Czerny as his Master, and himself as his disciple. To a certain extent, it repeats the situation of C. Czerny and L. Beethoven's relationship: the so eternally created history repeats its particularly successful acquisitions and plots.

1 Mueller R. C. Liszt's Indebtedness to Czerny // Carl Czerny : Komponist, Pianist, Pädagoge / hrsg. von Heinz von Loesch. Mainz [u. a.], 2010. S. 147-164. 


\section{C. Czerny and F. Liszt: a teacher and a grateful student}

Formally, C. Czerny taught F. Liszt for only 15 months: from about May 1822 to August 1823, when Adam Liszt insisted on continuing the performances of his genius son. Interesting reasons for which, at the first meeting with the young talent C. Czerny refused to teach him. Referring to his "Biographical Outline", R. Mueller explains this act by a popular music teacher "inherent to him - as well as his teacher Beethoven - dislike of young prodigies"2. Only a year and a half, without resisting the pressure of Adam Liszt, C. Czerny began to teach his son, becoming the first and last professional mentor of the future genius in the field of pianism. Fully appreciating the talent of a young student, the teacher directed his efforts to ride the whirlwind of his pupil's nature, practicing the technique and learning the discipline of hearing, mind and playing apparatus. Their new meeting took place only in 1837 in Paris, where F. Liszt invited C. Czerny to participate in Hexameron. Let us recall the essence of this project, the history of which is described in the article under consideration by R. Mueller. It was initiated by Christina Belgiojoso, "an Italian princess whose support for the struggle for freedom and the unification of Italy made her both a valuable politician and a burden to all her friends" ${ }^{3}$. Having emigrated to Paris, the princess opened a salon for artists, writers, musicians, and politicians. In early 1837, for the purpose of charity, she organized a concert, announcing the co-creation of F. Liszt, S. Talberg, F. Chopin, F.V. Pixis, K. Czerny, and A. Hertz in creating variations on the theme "Suoni la tromba" from the opera "Puritans" by V. Bellini. As a result, as R. Mueller writes, almost $75 \%$ of the implemented project is the work by F. Liszt. As R. Mueller writes, the former mentor was depressed by the state of pianism of a famous musician: indecision, carelessness, excessive bravado of his play, namely, false aesthetic ideas. As C. Czerny remembered, and the author of the article refers to, he advised F. Liszt to leave Paris and travel to Europe. Particularly beneficial was his last stay in Vienna, which resulted in his unrivaled but more restrained style, and earned him well-deserved fame.

No matter how short the time of F. Liszt's study was, R. Mueller considers him to be the executor of the technique created by his mentor.

2 Mueller R. C. Liszt's Indebtedness to Czerny // Carl Czerny : Komponist, Pianist, Pädagoge / hrsg. von Heinz von Loesch. Mainz [u. a.], 2010. S. 147-148.

${ }^{3}$ Ibid. S.161. 
This view makes it possible to see in the bold innovative achievements of the great romantic the solid foundation laid by his teacher, the performance model that creates a solid foundation for the reformist pianist style. In this way, C. Czerny's school, which had accumulated the experience of L. Beethoven and eminent virtuosos, proved to be a fertile ground for the flourishing of the Liszt pianist genius. R. Mueller writes that "in terms of training, we must admit that the early study of Liszt was not characterized by hard work - until Czerny accustomed him to the regime and discipline”. In his own pedagogical practice, F. Liszt was engaged not so much in the technique as in polishing his pianism skills, but "assuming that the foundation had already been laid by hard work" ${ }^{4}$.

C. Czerny's role in F. Liszt's musical fate is not limited to pianism and pedagogy. R. Mueller cites interesting facts that make it possible to appreciate it in the composer's practice of the famous reformer. The figurative ideas acquired through the tutor rooted firmly in F. Liszt's works of Weimar and the subsequent periods of his work ${ }^{5}$. Perhaps even more significant are the recommendations and reflections of C. Czerny concerning the composition mastered by his brilliant student. Reflecting on the art of improvisation, he identifies six types of implementation: the development of a single theme in all the types of composition formed; several topics that form a certain unity; potpourri flavored with brilliant passages and cadences, where several popular motifs are joined by simple modulation links; variations; improvisation - right down to the fugue; capriccio "with all its will and independence" ${ }^{6}$. F. Liszt took as a basis the types of the second (several-theme improvisation), the third (potpourri) and the sixth (capriccio), gradually melting them into their own ideas, which resulted in transcriptions, paraphrases, and memories. The goals of such compositions were also formulated by C. Czerny. They should be intended for youth education, recreation for amateurs, serve the dissemination of new music - demonstration of the virtuoso talent $^{7}$. The value of C. Czerny's recommendations for F. Liszt as a composer is proved by his appeals to the teacher with the help of which the already venerable musician shares his difficulties. Liszt's Transcendental Études have the dedication: “for C. Czerny with gratitude

4 Mueller R. C. Liszt's Indebtedness to Czerny // Carl Czerny : Komponist, Pianist, Pädagoge / hrsg. von Heinz von Loesch. Mainz [u. a.], 2010. S.150.

${ }^{5}$ Ibid. S. $154-155$.

${ }^{6}$ Ibid.

${ }^{7}$ Ibid. S. 158. 
as a token of friendly respect. His disciple F. Liszt”. Commenting on it, R. Mueller states that it was not only "the typical grateful courtesy of Liszt": the sincerity of the author of the dedication is evidenced by the signature "his disciple", and this was at a time when the master became "one of the greatest musicians of that era, whereas the glory of his teacher has already died" ${ }^{\text {. }}$. In the light of the content of the article, such a conclusion seems quite reasonable.

\section{C. Czerny's pianistic guidance in F. Liszt's early etudes}

F. Liszt's early etudes provide a great opportunity to establish direct inheritance with similar examples of the teacher, exposing the foundation on which the magnificent and dazzlingly beautiful temple of his pianism, crowned with sketches of transcendent mastery, will be erected. D. Jaworski considers F. Liszt's early etudes from other perspectives. He is interested in the process of developing a purely virtuoso orientation in interpreting the genre in the first two editions of Liszt's etudes into the complex artistic concepts of the third edition ${ }^{9}$. Our task is not to reveal the dynamics of genre modification of the composer's works, but, conversely, to uncover those stable properties of his pianism that relate the results of C. Czerny's and the reformist schools as the mature master. They date from 1825-1826, were written shortly after the end of his short-term study with K. Czerny, and proved to be a realized fragment of "48 Exercises in Major and Minor Tones of Young Liszt”. In domestic musicology their idea as sustained in the spirit of K. Czerny became entrenched. Some clarification of this characteristic is introduced by his colleague R. Mueller, whose opinion he refers to. According to him, despite the apparent similarity between C. Czerny's and F. Liszt's etudes, the former cannot be called models for the latter. In the context of such differences, it is advisable to subordinate the analysis of the youthful sketches of the future master to their comparison with the etudes of C. Czerny and to consider them as "transcendent".

F. Liszt's opera 1 is a sequence of etudes in a strictly organized system of quarto-quintus functional relationships, and from $\mathrm{C}$-dur

\footnotetext{
${ }^{8}$ Mueller R. C. Liszt's Indebtedness to Czerny // Carl Czerny: Komponist, Pianist, Pädagoge / hrsg. von Heinz von Loesch. Mainz [u. a.], 2010. S. 147.

9 Яворський Д. Ю. Етюд у жанровій системі романтичної фортепіанної мініатюри (на прикладі опусів Ф. Шопена, Р. Шумана, Ф. Ліста) : автореф. дис. ... канд. мистецтвознавства : спец. 17.00.03 / Нац. муз. акад. України ім. П. І. Чайковського. Київ, 2016. 18 с.
} 
movement occurs in a circle of tonalities not towards the sharp notes, as usual in such cases in the composers of the XIX century, but towards the flat notes: this is how the composer will make his future "transcendence". Each major etude corresponds to a minor in a parallel tone. Therefore, the purpose of the cycle is to master the pianistically all (in this case, twelve) tonalities with the coverage of white and black keys, that is, the topic of the instrument, individualizing the texture of each etude, not only its virtuoso elements, but also the party of accompaniment. As in any "School", including C. Czerny, numbers of the collection are built on the principle of increasing complexity: from scales and arpeggios to double notes, wide intervals, asymmetric simultaneous execution of complex figures. The main focus is on manual techniques, which F. Liszt will later declare the most difficult in its classification of "fundamental formulas" ${ }^{10}$. C. Czerny's system is implemented in the early etudes of the composer and grows into the principles of his pedagogy - along with the tendency to any kind of systematization. Equally noteworthy are the encyclopedic claims of young F. Liszt to appeal to the many pianistic formulas, bringing his etudes closer to the exercises of C. Czerny. All etudes contain metronomic instructions. Most of them are written in the Allegro tempo, though Moderato and Allegretto are also used. Tempo instructions, as a rule, are provided with figurative ones too: con fuoco, molto agitato (instead of tempo), con molto espressione, con spirito, grazioso. Attention to the performance instructions indicates the author's wishes to those who play his etudes, not to turn them into "finger gymnastics", but to conceive as a musical composition, taking care of the meaningfulness of their sound reproduction, which is impossible not to associate with similar intentions C. Czerny. An ideally smooth, clear, endearing, "clever" game based on the discipline of performing movements, hearing, willpower - all this is the example of C. Czerny's pianism, which should be a guide for the performer at all stages of his work, including training. Vasylets notes that "many of the students when mastering the works by C. Czerny (instructive etudes) mainly concentrate on technical problems in the narrow sense of the word. They

10 1. Буасье А. Уроки Листа / пер. с фр., вступ. ст. и коммент. Н. П. Корыхаловой. СПб. : Композитор, 2002. 75 с.

2. Будяковский А. Е. Пианистическая деятельность Листа. М.; Л. : Музыка, 1968. 85 с.

7. Мильштейн Я. Ф. Лист. В 2 т. Т. 2 : монография. 2-е изд., расшир. и доп. М. : Музыка, 1971. 600 с. 
give attention neither to articulatory nor to dynamic tasks; thus, not only the meaning and purpose of the etudes are significantly impoverished, but also, in essence, the textured problem posed by the composer is not solved, since their work is mechanical, without activation of hearing”. Developing this thesis, the author asserts that the benefits of working on instructional etudes will be greater than the "more complex musicalaesthetic tasks", and specifies that "concerning the etudes, musicalaesthetic tasks relate to sound quality, sound equality, timbre, sound, tempo", which are the essence of the aesthetic ideal of C. Czerny's pianism $^{11}$. They determine the attitude to the training etude inherent in F. Liszt. At the same time, in his early etudes, written before F. Liszt's fateful discovery of N. Paganini's art, there was a characteristic that would determine the composer's mature pianism, including his sketches: the concentration of various play figures in a single sample. They develop texturally and thematically due to their change - until the emergence of relief contrasts that organize the musical form. Equally diverse is the set of authors' figurative and articulate remarques, dynamic nuances, which can be interpreted as a continuation of C. Czerny's experiments on bringing the etude closer to the play and, at the same time, predicting own path aimed at balancing differences between genres of musical art and establishing interspecies relationships based on the principle of programme. Finally, the restless temperament of a young genius requires the shifting of the register-sound framework of "pure" piano due to the coverage of the entire keyboard, the accumulation of the volume of the chord verticals, the speed of "run" of scale-like passages. In this way, F. Liszt's early etudes clearly show how etude details of the future building begin to emerge over the foundation laid by C. Czerny, as his own "voice" of the future master erupts at this early stage of his pianistic formation.

Etude No. 1 (C-dur, Allegro con fuoco) demonstrates similarity to C. Czerny's exercises, which are designed to nurture the ability to change pianistic figures, revealing Czerny's counterparts of the Liszt concentration of techniques, which received an additional powerful impetus from N. Paganini. The same figure or clutch of different formulas is either repeated at different heights in the form of a sequence,

11 Василец В. В. Технические опусы Карла Черни в современном учебном репертуаре // Формування творчої особистості в інформаційному просторі сучасної культури : зб. наук. пр. / упоряд. М. П. Калашник ; ред. В. М. Алтухов. Харків : Основа, 2004. С. 130-131. 
or reproduced literally. F. Sheet generously sets out strokes - staccato, tenuto, legato, accents, dynamic hues, вилки, often denotes a climax approach with the help of a long-lasting crescendo. The texture of the accompaniment rages with melodious expressive intonation turns, and the musical texture as a whole is stratified in 3-4 plans. There are no indications of the pedal press up to the last strokes, which are arpeggios through the entire keyboard with the change of hands. All sixteenthform, uniformly sounding figures require perfect sound evenness and accurate finger diction.

Etude No. 2 (a-moll, Allegro non molto) uses broken octaves alternately with the right and left hands, the upper voice of which, playing with 4-5 fingers, form a melody line, repetitions, circular motions, homogeneous passages, arpeggios. It also applies the principle of repeatability not only of individual figures, but also of rather large structures in order to achieve a certain technical result. In the accompaniment party, a chord-rhythmic pulsation with an accentuation of the strong fate of the beat alternates with melodic blinks. The change of figures is emphasized either by remarques (molto leggiero, dolce, marcato), or dynamic shades. Before the reprise, it is recommended to slow down a bit, which allows highlighting this compositional section, which at the same time acts as the culminating section of the etude.

As in the previous case, the textural and thematic elements of the etude No. 2 were given a new start of life in their tone counterpart, created in the mature period of F. Liszt's work. The composer renounces any genre or program name, giving freedom to his pianistic fantasy. And the starting point is the juxtaposition of textured-themed figures melodized and figurative. The further course of the music process does not coincide. As for the borrowed eight bars, they can be considered as two variants of a single complex, which differ due to the qualitative transformations of Liszt pianism in his reformist capacity.

The young author reveals a wonderful fantasy in the etude No. 3 (F-dur, Allegro semper legato). Taking for the operative unit the same initial figure as in the previous one, he varies it, places at different altitudes in the form of a sequence, then changes the interval composition, without losing the smoothness of the line of upper sounds, passing from one hand to the other, but in overall following the equirhythmic motion of the eighth in both. Of particular interest are variations such as tonal, including long-range $(b-$ moll $)$ variation, and especially partial or complete separation of the melodic movement of the upper sounds from the figurative context, which is clearly expressed in 
the last strokes of the sketch when melodized. the descending line is laid out by the left hand in an octave, in dashed rhythm, of great duration in the $f f$ nuance.We should also note the intonational complexity of the etude, caused by many chromatized moves and deviations in other tonalities. Equally interesting is the dynamics, where, along with the phrasing вилки and crescendo, the principle of "terraced" $p$ and $f$ is actively used. Volume instructions also perform a composite function. In particular, the transition to $b$-moll darkening the vivid tone palette is highlighted by the $p p$ nuance. All this, first, generates a hidden fourvoice texture, and secondly, transforms the training figure into a factor of thematic expressiveness and form-making, that is, in the presence of the feature of the play. It is obvious that F. Liszt's intentions as author are directed not only to the discovery of technical difficulties, but also to the composer's work. Of course, there is no need to talk about the deep imaginative content or complexity of the artistic concept; rather, it must be about admiring the process of communicating with the instrument, playing music and pianism, and yet it cannot help but admire the relaxed and creative generosity of a young genius, who is manifested even in instructional opus. Moreover, the creative forces are not only manifested in their game as a "burst" of natural energy, but also in the creation of a directly game situation, when the melodious voice hidden in the selected figure first hesitantly declares itself, then more persistently breaks its way and finally flows into a self-proclaimed, thunderously-spoken phrase: the secret becomes obvious. From this perspective, the F-dur etude is perceived as a mystery play - a tribute to the teenage boy's worldview. In the future, F. Liszt will show the play principle in a relaxed fantasy, grotesque imagery, the technique of "return", and in the later play "Fountains of Villa d'Este" from his third volume "Years of Travels" - in the musical embodiment of the eternal source of life, that radiates all the colors of the rainbow and sound highlights.

Similar to the development of the figurative idea No. 2 in etude No. 3, etude No. 4 (d-moll, Allegretto) picks up a line of double notes missed in the previous one. This small play is based on the alternation of two textured types of musical material, the presentation of which involves the solution of two training problems: equal play with parallel tertiary, transmitted from one hand to the other, and the execution of arpeggio figurines placed "inside" octaves, the sequential formation of which melody line. The etude is generously filled with signs of dynamics, phrase вилки, accents, $s f$, crescendo remarques, i.e. recommendations of the executive plan that stimulate the attitude to the 
instructive sketch as a musical phenomenon, which excludes the mechanical training of the pianist apparatus.

An interesting re-melting of the manual formula for the transfer of friction sequences from one hand to the other used in this etude is presented in Mazepa, where it forms the middle layer of a three-line score. In the context of the program and the general tone of the music given to this etude, this formula acquires a very specific extra-musical content, associated with a running horse of a "wild hunter" - a rebellious hetman running with all his might.

Against the backdrop of a miniature intermezzo of etude No. 4, the next one - etude No. 5 (B-dur, Moderato) - seems like a giant etude. Even a cursory glance at it gives us the impression of a play in front of us. The etude is based on the principle of a two-voice presentation of the right-hand party, which combines the melodious and graphic melody voice with the tertiary counterpoint, which acoustically fills the vertical. In the party of the left hand, the accompanying octaves measure the fate of the beat, alternate with the headers and chords, and the combination of the two harmonic vertices occurs with a violation of metricity. The etude techniques appear as a shade contrast and contain a variety of figures in a uniform (twist) movement of the sixteenth: homogeneous passages of mixed type (a compound of diatonics and chromatics), arpeggio, alternation of different intervals, etc. The obvious focus is not on the processing of one formula, but on the formation of flexibility in their constant change, the ability to quickly transform movements, the coverage of large structures as a single, internally differentiated structure by hand, hearing, and vision.

In contrast to etude No. 5, the following is etude No. 6 ( $\mathrm{g}$-moll, Molto agitato) of a single texture. F. Liszt fills each party with hidden and clear voices. In the right hand, the lower voice is graphically and rhythmically highlighted, and the upper, the sounds of which are added by the chord vertical, contains tenuto signs, resulting in another melody voice. The wide jumps in the left hand also split into two voices: melody and bass, with special leagues indicating the need to combine them so that the bass note alternates with the melody.

Graphics of etude No. 7 (Es-dur, Allegretto con molto espressione) brings to mind the textural discoveries of F. Chopin and F. Liszt himself, who were to be born in the coming decades. Parallelism of the three-tone verticals in the right hand, the combination of a wide-ranging arpeggio with a chromatic descending range, a converging and divergent hand movement, with an alternate stroke, a dense chromatization of the fabric 
with mastering the play on white and black keys, a large range of sounds - all of this style, dating from the collapse of the 1820-1830s, the eve of F. Chopin's first etude opus. Etude No. 7 of the concert features is complemented by a small virtuoso cadence, which is contained in its last bars. It should be noted that young F. Liszt generally worries that the extremities of the etudes included in the collection are as effective as possible, so he associates their final bars with unsurpassed arpeggios, chords and octaves, etc. In this etude, this technique is implemented through the attributes of not only the concert play, but also the genre of the concert. It is noteworthy that cadence is preceded by a dominant fermata and a trill.

By expansion of scales, level of dynamics, intensity of tonal development, etude No. 8 for the left hand (c-moll, Allegro con spirito) exceeds all previous ones. It builds a complex three-part reprise form with a developed multiphase midpoint, indicated by intense tonalharmonic motion - up to the capture of E-dur, a-moll, d-moll, that is, distant relative to the central $c$-moll structure. The theme is based on one melodic idea, subject to tonal and modal rethinking. It is presented with the right hand in the form of full-sounding chords, including the top voice, while the left hand performs passages of different configuration, running evenly. In the links between the statements in the extreme sections, in one of its statements a figure-motor initiative goes on average to the right hand or involves both hands. In the second case, the passages are duplicated in an octave. The very theme of the etude contains a conflict situation, formed by two elements, which corresponds to the ask-question construction of the main themes of the sonatasymphonic Allegro, causing a dramatically intense tone of the etude. Dynamic tones serve to the same goals ( $f$ and $f f$ in the "strong" element, $p$ - in the "weak"), as well as wide coverage of the keyboard. The similarity of technological and expressive ideas of the etude $c$-moll by F. Liszt and the etude of op. 10 No. 12 in the same tone ("Revolutionary") by F. Chopin is symptomatic. It is not only due to their physiognomic likeness, but also to the orientation of the ways in which both composers melt the elements of "pure" pianism into a factor of artistic expression, and the training task - into the way of personal expression.

In the context of the entire collection, etude No. 8 is a dramatic climax. It is located at the point of "golden intersection" - a clear indication of the design of the twelve numbers as a cyclic composition. Etude in the same tone, placed in a cycle of "transcendental", is as dramatic and is perceived as one of the peaks in the expression of the 
letter expression, though not the only one. In order to embody the image labeled "Wild Hunt" in the program title, the composer adds two or three strokes and, accordingly, transforms the primary theme of the youth version. It replaces the flying, arched passage of the left hand with an octave martellato, and saturates the theme with the right with a sharp dotted line, depriving the second element of the function of the "weak" and laying it with chords in both hands. The following etudes tend to diversify the lyrics and the narrowness and completely move to the level of the etude-plays.

The most intimate statement is etude No.9 (As-dur, Allegro grazioso). Its texture is clearly divided into theme tune and accompaniment. The melody line begins with a group with a sixth motion, abounds with detentions, chants, and rapid homosexual takeoffs ornament it, anticipating the techniques of F. Chopin's cantilever. The accompaniment party is made in the spirit of nocturnal wide arpeggios, which give the music specific "piano" phonism, enhanced by the exhibited - first ever in the collection! - pedal. Signs of the hidden, the passionate lyrics are complemented by the remarques con leggierezza e espressivo, con dolore, con molto espressivo, and in the climax, where the sound array of closely spaced chords reaches almost orchestral power, the melody shows signs of F. Liszt's beloved declamation (portamento remarque). Those who play this etude must achieve a delicate, and in the climax - full-sounding carcasses, jewelry "diamond" in almost weightless passages (Leggiero trailer) and a sequence of trills before the reprise, as well as mastery of the pedal. The sketch ends with a brilliant cadence, ended with the same melodic figure as it started with (dominant with a sixth-quint with a subsequent resolution to a keynote).

Compared to the "Memories" etude, its older "relative" seems to be a preliminary etude. The "Transcendent" version retains not only the basic musical thought, but also some details of its design - the group followed by a wide jump, interruption of the melodic expansion with figurative ornament and cadence constructions, as well as the general dramatic plan of the work. Of course, all this occurs given the reformist achievements of F. Liszt in pianism. This is the first case of such a complete coincidence of two variants of a sketch, which is not surprising, since the youthful sketches of As-dur stand out with all the trappings of a holistic emotionally-expressive expression, including the expressiveness of an intonationally individualized melody and a clearly thoughtful "lyrical drama”. 
The lyrical beauty of the etude As-dur is emphasized by the intrinsic suddenness of etude No. 10 ( $f$-moll, Moderato). In texture, it is much closer to the genre invariant, being an equirhythmic uniform motion of the sixteenths in both hands at intervals of septim and decim. The repetitiveness of pianistic formulas and small constructions again makes one remember C. Czerny's exercises. However, the endurance of the tarantella rhythm, the precise calculation of the three climaxes, the second of which is marked with a con fuoco remarque, persistent crescendo with the conquest of a huge sound space creates a sense of elemental play - a mysterious and then a powerful wave, like a natural phenomenon or the world of human passions. Particularly striking is the end of the etude, when the freely rhythmic ascent from $C$ to $f^{4}$ in the nuance $\mathrm{ff}$ is interrupted by two chords, and then the bass resumes the tarantella movement, descending to $\mathrm{F} 1$ with rapid movement to $p$.

Synchronization of parties of right and left hands in the interval ratio of decimas is characteristic of etude No. 11 (Des-dur, Allegro grazioso), but its texture is significantly complicated up to four layers, two in each hand, and with its technical complexity. In the right tune, the octave is alternated with the spatial "sky" - the sound des; in the left hand, due to the sustained bass height (des two octaves below), complementary rhythm occurs. Throughout the etude, the texture is repeatedly maintained with the retention of four voices. It pauses only once to perform the chromatic descending scale by parallel major sequences. The scale study contains an image contrast in the middle of a complex three-part reprise: a new theme con dolore in cis-moll with active thematic and tonal development. It uses the turn quintoles with the following expressive moves on the sixth and octave, the veiling of melodic relief, the isolation of lamentous choreic motifs, i.e. a set of techniques attributing lyrical expression.

The final in the cycle of early etudes is etude No. 12 (b-moll, Allegro non troppo), instructively designed to produce melodic plasticity of the upper voice of a harmonious figure in the right hand and bass voice in the left with synchronized movement of both. The etude starts with a small introduction, which already contains the chosen technical condition. This start immediately sets the perception of the thematic and dramatic content inherent in the play. Throughout the etude, the composer maintains the melodic completeness of the utterance, carrying out an intonational variation of the monotheme, aimed at its figurative transformation in expressive climax, where it is performed in bass octaves, ff - fff, marcato instead of $p$, dolce, con molto espresivo. As in 
the previous etude, F. Liszt refuses a spectacular end, preferring to the long ostinato of figurations that sink into diminuendo, followed by $p p$.

The well-found theme and its textural solution led to the re-use of these musical ideas in the "Snowstorm" etude, written in the same tone, which is also a closing cyclic composition. However, both turned out to be subordinate to the program design. The melody relief is a dashed line, each short sound of which is distinguished by the portamento sign, which, in the conditions of quiet dynamics and high register, causes the feeling of light, fleeting touches. The background material also gives the impression of something fragile, weightless, volatile - extra-musical associations typical of romantic imagery. Since it is not an impressionistic music landscape, but rather a lyrical story, the dramatic script of "Snowstorm" reminds its predecessor - an early $b$-moll etude: a gradually releasing energy flows into an expressive climax with a subsequent decrescendo. However, unlike its prototype, the concert play ends with a spectacular "throw" of tonic chords through the entire keyboard, emphasizing the final solid $s f$ and thus giving a clear "point" - the end mark of the whole cycle. The pianistic paints of mature Liszt pianism in Snowstorm cannot be compared with the modest, chamber design of the identical melodic idea of the instructive sample, but it also contains a considerable share of manual techniques, though subordinated to other targets.

Comparison of F. Liszt's early and "transcendental" etudes is not only useful for the visual presentation of the path the pianist had undergone in the thirty years of his performing career. Much more important is the opportunity arising through his mediation to discover, both in the student's works of the outstanding musician, and in his mature creations of the teacher's covenants - at all the great distance separating the harmonious, aesthetized ideal of the "beautiful play" cultivated by C. Czerny, and the excess the superfluous, fanciful spontaneity of the expression manifested by the "frantic play" and by F. Liszt's works. From the point of view of C. Czerny's school, its Russian-Ukrainian "sprout" can be considered a branch that integrates the concert and pedagogical practice of another prominent pupil of C. Czerny T. Leshetitskyi and his pupils A. Esipov and V. Pukhalskyi. The named triad, which developed a single set of didactic principles, presented in the theses by Zh. Dedusenko ${ }^{12}$. On V. Pukhalskyi’s pianism ${ }^{13}$.

12 Дедусенко Ж. В. Исполнительская пианистическая школа как род культурной традиции : дис. ... канд. искусствоведения : спец. 17.00.01 «Теория и история культуры». Киев, 2002. 208 с. 


\section{C. C zerny's pedagogical heritage in scientific studies of art experts}

The succession of C. Czerny's school to his distinguished student is though convincing, but not the only evidence of the high efficiency of the method he created, embodied in numerous collections of etudes and exercises. Equally important are the arguments that support her innocent vitality, cited by researchers and music educators who summarize observations of the educational repertoire of modern piano classes. Based on his own experience, Thomas Just believes that the leading place among the creators of instructional materials belongs to C. Czerny ${ }^{14}$. He assigns a special role in the pedagogical repertoire to the "Fluency School" op. 299, aimed at learning the manual play. However, T. Just calls "160 eight-stroke exercises" op. 821 the most fundamental pedagogical creation of C. Czerny, which "involved all the technical material necessary for the development of classical works"15. He writes about their work, constantly referring to their author by means of a rich quotation. In particular, he draws attention to the techniques of sound formation, producing a "beautiful and powerful blow", the ability to achieve a smooth and meaningful play of $p$ and $f$-skills that $\mathrm{T}$. Just, after C. Czerny, consider important components of the technical process $^{16}$. T. Just believes that "if a pianist trains properly, if he works out a good sound formation during technical exercises, etudes, only then he can meaningfully use C. Czerny's etudes" "17. Two statements by V. Margulis serve as a clear argument for this thesis: "You can turn the $C$ dur range into a declaration of love. And you can freeze beautiful music by turning it into a soulless finger exercise". And even more convincing: "Do not be afraid that the source of your inspiration may be buried under hours of exercises. Rather, you should be afraid of the technical helplessness that raises the dams against the current of your inspiration!" ${ }^{18}$.

13 Курковський Г. Питання фортепіанного виконання : зб. ст. Київ : Муз. Україна, 1983. 139 с.

Рощина Т. Владимир Вячеславович Пухальский (1848-1933), основоположник киевской фортепианной школы // Київське музикознавство : зб. ст. / Київ. держ. вище муз. уч-ще ім. Р. М. Глієра. Київ, 2004. Вип. 13. С. 117-126.

14 Just T. Czernys Bedeutung für die Klavierausbildung heute // Carl Czerny : Komponist, Pianist, Pädagoge / hrsg. von Heinz von Loesch. Mainz [u. a.], 2010. S. 91-96.

\footnotetext{
${ }^{15}$ Ibid. S. 92.

${ }^{16}$ Ibid. S. 93.

${ }^{17}$ Ibid.

18 Ibid. S. 95.
} 
If T. Just comes from his own teaching practice in evaluating C. Czerny's instructional materials in terms of their relevance, then L. Grossman relies on a variety of sources, among which she cites curricula, note publications with instructions, exam requirements, specific educational institutions, methodological literature, as well as the content of conversations with colleagues and statements of concert pianists ${ }^{19}$. In particular, she cites data from the Siegfried Lemsted 1982 curriculum for specialized schools, the curricula of ordinary music schools in 1974, the unions of German music schools in 1981, as well as Rolan Conim, Denis Pascal, Francois-Michel Rignon (respectively, the Conservatories of Avignon, Paris Perpignan) in 2002. Expanding the geography of her observations, L. Grossman draws on the methodological materials of Hungarian teacher Marianne Teske, published in 1982, by Czech authors Elishka Kleinova, Alena Fischerova, and Eva Miullerova, referring to 1965, and refers to a series of etudes by C. Czerny, published by Zen-on piano library. Particularly thoroughly L. Grossman studies the methodical experience of using the etudes and exercises of C. Czerny $\mathrm{n}$ musicians and educators, first of all, Anna Artobolevska. Referring to the documented pedagogical practice of different countries and, accordingly, national and author's schools, gives L. Grossman the right to make three fundamental conclusions: piano education always involves the active and systematic mastering of C. Czerny's instructive inheritance; all programs are dominated by collections of op. 299, op. 740, op. 821, for primary education - op. 139 , op. 261, op. 599, for highly experienced pianists - op. 365; other works of the composer, even those that could greatly benefit from the improvement of performing skills, do not play any role in piano education.

Of particular interest are the reflections of L. Grossman on the causes of the inevitable popularity of studies and exercises of C. Czerny, objectively confirmed by her research. She sees important the coincidence of the dates of his life and contemporary composers - from L. Beethoven and J.N. Gummel to F. Liszt and G. Biulov, so that «he was familiar with the main directions of the clavier music of the second half of XVIII and the first half of the XIX century, whose characteristic stylistic features are reflected in his sketches”. The author also mentions the publication of the works by J.S. Bach and D. Scarlatti, whose sonata,

19 Grossmann L. Czerny in der zeitgenössischen Klavierpädagogik // Carl Czerny : Komponist, Pianist, Pädagoge / hrsg. von Heinz von Loesch. Mainz [u. a.], 2010. S. 97-129. 
the researcher recalls, were initially referred to as the exercises, "and in the future were probably a model for writing training plays" 20 .

No less important circumstance that ensured the long life of C. Cerny's instructional experiences, L. Grossman considers the prediction of the elements of "virtuoso clavier writing" a great educator, proving her observation by reference not only to F. Liszt's early sketches, but also to the "transcendental" ones that found "a close affinity with the etudes of his former teacher C. Czerny"21. Specifying the thesis, L. Grossman lists formulas from C. Czerny's etudes and exercises "that look to the future". They include a fast passage play through the entire keyboard "with one pulse"; rapid change of hands, partly in martellato, and rearrangementinterweaving of hands; glisando with double notes; agogically freely constructed passages with regular-metric accompaniment (as in the nocturnas not only by J. Field but also F. Chopin); widely spaced intervals ${ }^{22}$. L. Grossman finds in some exercises an analogy with the piano works by F. Chopin and F. Liszt and concludes that C. Czerny's instructive inheritance is not limited to the cultivation of purely manual technique, which is evidenced by the considerable number of octave and chord exercises. On the example of op. 821, L. Grossman brings C. Czerny's attention to the designation of the tempo, character, nuances, and even establishes the regularity of the tonal movement in the quarto-quintile circle toward the flats - a natural coincidence with the similar sound-level structure, which we have noted in the collections of both F. Liszt's early and transcendental etudes ${ }^{23}$. At the end of her substantial article L. Grossman provides many names of concert pianists, whose technical training and even the maintenance of the performing form occupy a significant place in the studies and exercises of C. Czerny. Among them, Jean-Marie Darreux, a student of Margarita Long, is familiar with some of F. Liszt's recent pupils, Robert Casadesus, Jose Iturbi, and others. Here is also an important comment of the author that "Czerny's etudes are not only excellent training material, but also can bring to the performer an understanding of the development of clavier music" ${ }^{24}$.

20 Grossmann L. Czerny in der zeitgenössischen Klavierpädagogik // Carl Czerny : Komponist, Pianist, Pädagoge / hrsg. von Heinz von Loesch. Mainz [u. a.], 2010. S. 108.

${ }^{21}$ Ibid. S. 109.

22 Ibid. S. 109-111.

${ }^{23}$ Ibid. S. 119-120.

${ }^{24}$ Ibid. S. 129. 
Thus, the study of the role of C. Czerny and his school in F. Liszt's music practice, the analysis of the early sketches of Hungarian romance, the study of the place of instructional materials of a famous musicianteacher in modern academic practice make it possible to objectify and scientifically substantiate their importance for maturation of the immediate representatives of C. Czerny's school, and of the subsequent generations of pianists up to the present.

\section{CONCLUSIONS}

The combination of purely utilitarian, motor-physiological, preparatory with aesthetically meaningful, and sometimes figurativeexpressive meanings in the etudes and exercises of C. Czerny contributed to their "germination" in the pianism and compositional experiments of his famous pupil F. Liszt, whose work opened a new stage in the development of piano music. As the analysis of his early etudes with a projection on mature samples of the genre showed, the path of the famous converter of musical art led from the continuation of the traditions of his school to their "removal" in his reform. Moreover, until the very death of C. Czerny, the communication between the teacher and the student, on other, freely creative grounds, continued constantly, which testifies not only to mastering the school methods of the teacher, but also to the exchange of artistic and aesthetic ideas and views.

The coverage of the entire panorama of the pianistic technique of that time, the clear differentiation and systematization of its characteristic techniques, the perfect logic, the systematic thinking of C. Czerny testify that the 12 early and "transcendental" etudes of F. Liszt are the embodiment of a holistic pianistic didactic system. The early opus written shortly after classes with C. Czerny retains traces of unforgettable lessons. The systematic nature of the collection, which manifests itself in the arrangement of the etudes according to the types of difficulties, the desire to cover all the tonalities of major and minor, the white and black keys of the instrument, the variety and variability of the available formulas clearly indicate the inspirational impulses emanating from the etudes and exercises of the teacher. F. Liszt also does not forget that the instructional etude is a piece of music, and accompanies everyone with performance remarques, and sometimes with pedal signs. The comparison of the composer's early and "transcendental" etudes clearly shows the pianistic frame that will be preserved in his reformist opus, that is, the heritage of C. Czerny's school. With all the orchestration of the sheet feeling of the piano, the texture of his works is always pianistic, naturally in contact with the piano and executive apparatus - and this is also the result of Czerny's school. 


\section{SUMMARY}

Thus, the study of the role of C. Czerny and his school in F. Liszt's music practice, the analysis of the early sketches of Hungarian romance, the study of the place of instructional materials of a famous musicianteacher in modern academic practice make it possible to objectify and scientifically substantiate their importance for maturation of the immediate representatives of C. Czerny's school, and of the subsequent generations of pianists up to the present.

The same features help C. Czerny's etudes and exercises retain their appeal for contemporary pianistic practice. No training program designed for students of different levels can do without a large number of samples, which provide continuity in the formation of playing skills, on the one hand, meaningful playing on the instrument, even on the training stage, on the other. The research interest in the phenomenon of the endless life of C. Czerny's methodological collections, both as an indestructible fact and as a puzzle to be solved, speaks for itself.

Much new in understanding the merits of C. Czerny in musical culture was found in the XXI century. Analyzing his heritage - both creative and practical, contemporary researchers record the appeal to the instructional materials of a famous teacher at all stages of training young musicians in many European and Asian countries. Asking about the reasons for their continued interest in teachers from different schools, they find in C. Czerny's etudes and exercises not only their utilitarian advantage, but also their value in understanding the logic and stages of pianism, and, most importantly, belonging to music as to the art of intoned meaning, according the formula of B. Asafiev.

\section{REFERENCES}

1. Буасье А. Уроки Листа / пер. с фр., вступ. ст. и коммент. Н. П. Корыхаловой. СПб. : Композитор, 2002. 75 с.

2. Будяковский А. Е. Пианистическая деятельность Листа. М. ; Л. : Музыка, 1968. 85 с.

3. Василец В. В. Технические опусы Карла Черни в современном учебном репертуаре // Формування творчої особистості в інформаційному просторі сучасної культури : зб. наук. пр. / упоряд. М. П. Калашник ; ред. В. М. Алтухов. Харків : Основа, 2004. С. 126-135.

4. Дедусенко Ж. В. Исполнительская пианистическая школа как род культурной традиции : дис. ... канд. искусствоведения : спец. 17.00 .01 «Теория и история культуры». Киев, 2002. 208 с. 
5. Курковський Г. Питання фортепіанного виконання : зб. ст. Київ : Муз. Україна, 1983. 139 с.

6. Лист Ф. Юношеские этюды: для фортепиано. Соч. 1 / ред. Л. Просыпаловой, Н. Судзаи. М. : Музыка, 1967. 52 с.

7. Мильштейн Я. Ф. Лист. В 2 т. Т. 2 : монография. 2-е изд., расшир. и доп. М. : Музыка, 1971. 600 с.

8. Рощина Т. Владимир Вячеславович Пухальский (1848-1933), основоположник киевской фортепианной школы // Київське музикознавство : зб. ст. / Київ. держ. вище муз. уч-ще ім. Р. М. Глієра. Київ, 2004. Вип. 13. С. 117-126.

9. Яворський Д. Ю. Етюд у жанровій системі романтичної фортепіанної мініатюри (на прикладі опусів Ф. Шопена, Р. Шумана, Ф. Ліста) : автореф. дис. ... канд. мистецтвознавства : спец. 17.00.03 / Нац. муз. акад. України ім. П. І. Чайковського. Київ, 2016. 18 с.

10. Grossmann L. Czerny in der zeitgenössischen Klavierpädagogik // Carl Czerny : Komponist, Pianist, Pädagoge / hrsg. von Heinz von Loesch. Mainz [u. a.], 2010. S. 97-129.

11. Just T. Czernys Bedeutung für die Klavierausbildung heute // Carl Czerny : Komponist, Pianist, Pädagoge / hrsg. von Heinz von Loesch. Mainz [u. a.], 2010. S. 91-96.

12. Mueller R. C. Liszt's Indebtedness to Cherny // Carl Czerny : Komponist, Pianist, Pädagoge / hrsg. von Heinz von Loesch. Mainz [u. a.], 2010. S. 147-164.

13. Pascall R. Czerny, der Symphoniker // Carl Czerny: Komponist, Pianist, Pädagoge / hrsg. von Heinz von Loesch. Mainz [u. a.], 2010. S. 191-226.

\section{Information about the author:} Genkin A. A., Candidate of Art Criticism,

Elder teacher of «FortepiaNo. Orgel», Dnipropetrovsk M. Glinka Academy of Music 10, st. Foundry, Dnipro, 49000, Ukraine 